\title{
Comparison of flexural and shear properties of southern pine LVL and lumber from young plantation and natural stands*
}

\author{
EJ Biblis \\ School of Forestry, Auburn University, \\ Auburn, AL 36849, USA \\ (Receveid 24 August 1994; accepted 30 April 1996)
}

\begin{abstract}
Summary - Edgewise flexural strength and stiffness values are reported of southern yellow pine $\left(5.08 \times 10.16 \mathrm{~cm}^{2}\right)(2 \times 4$ ) laminated veneer lumber (LVL) made from veneers of 20 -year-old plantation trees, veneer of 28- and 40-year-old trees of natural stands, and LVL composites made by mixing veneers of 20- and 40-year-old trees. The obtained flexural properties of LVL were correlated to veneer thickness and grade as well as to tree age. Flexural and shear properties of LVL are compared to properties of solid lumber obtained from the same groups and quality of trees. The distribution of allowable design flexural strength ' $\mathrm{Fb}$ ' and stiffness ' $\mathrm{E}$ ' corresponding to SPIB-91 lumber grades of various LVL groups determined.
\end{abstract}

laminated / veneer / lumber / southern pine / plantation

Résumé - Comparaison des propriétés en flexion et cisaillement de poutres de bois massif reconstitué et de bois massif de pins du Sud provenant de plantations et de peuplements naturels. Des poutres en bois massif reconstitué ( $L V L)$ sont réalisées à partir de placages déroulés (section 5,08 $\times 10,16 \mathrm{~cm}^{2}$ ) de pin (Pinus taeda $L$ ). Trois type de poutres sont testées en flexion sur chant et en cisaillement. Elles sont réalisées i) à partir de placages déroulés dans des pins de plantation âgés de 20 ans, ii) à partir de placages d'arbres âgés de 28 et 40 ans provenant de peuplements naturels et iii) en mélangeant des placages d'arbres de plantation et des placages d'arbres de 40 ans. Les mesures de flexion obtenues sont corrélées à l'épaisseur des placages et à leur classement ainsi qu'à l'âge des arbres. Les propriétés de flexion et de cisaillement du LVL sont comparées aux propriétés du bois massif mesurées sur des arbres comparables en âge et qualité. Les distributions de contrainte admissible $(F b)$ et de module d'élasticité admissible $(E)$ qui sont définies dans les règles de classement du LVL (SPIB91) sont déterminées et présentées.

bois massif reconstitué / placage déroulé / poutre de bois massif / pin du Sud / plantation

*This paper is based on a study supported by McIntire-Stennis funds (Project AL-974) and by the National Research Initiative Grant USDA-92-37103-8030 and is published as Alabama Agricultural Experiment Station journal series no 9-933491. 


\section{INTRODUCTION}

It has been reported that lumber from young loblolly and slash plantations are much weaker in strength and stiffness than lumber from older natural stands and that lumber from young plantations does not meet the design requirements for the visual lumber grades (MacPeak et al, 1990; Biblis et al, 1993). This is due to the fact that lumber from younger planted trees contain large percentages of fast grown 'juvenile' wood and a large number and size of knots (Pearson and Gilmore, 1971, 1980; Bendtsen, 1978; Bendtsen et al, 1986).

This study was primarily undertaken to investigate whether the veneer laminating process could significantly improve the properties of laminated veneer lumber (LVL) fabricated from veneers of 20-yearold plantation trees as compared to lumber properties of the same trees. Additional objectives of the study were to determine the properties of LVL from a 28- and a 40-year-old natural stand and compare them with the properties of the LVL from the 20-year-old plantation stand. Finally, this study investigated in a limited way the degree of improvement in flexural properties of LVL fabricated from 11 and eight veneer plies of 20-year-old plantation trees reinforced with two and four veneer plies, respectively, from 40-year-old trees of natural stand.

LVL has been studied and commercially produced for several years in the United States (Moody and Peters, 1972; Nelson, 1972; Koch, 1973; Bohlen, 1975; FPL, 1977; Kunesh, 1978; Laufenberg, 1983). Present production of LVL utilizes mostly $0.32 \mathrm{~cm}(1 / 8$ inch ["]) thick veneers, although veneers $0.25 \mathrm{~cm}\left(1 / 10^{\prime \prime}\right)$ and 0.16 $\mathrm{cm}\left(5 / 32^{\prime \prime}\right)$ thick are also used. The main reasons for the commercial production of long-length LVL with veneer scarf or overlap staggered joints are because it enables production of boards of larger width and length than sawn lumber. In addition, it provides relative uniformity in strength and stiffness, which results in higher design strength and stiffness values than sawn lumber produced from logs of the same species, size, age and quality. The improvement in strength and stiffness is primarily due to the reduction in size and redistribution of defects (knots and slope of grain) by the laminating process.

Another reported advantage of LVL production is the improved yield of lumber (FPL, 1977; Laufenberg, 1983). The improvement in yield is due to kerfless cutting of veneer. However, the improvement in yield alone does not economically justify the production of LVL. The degree of improvement in strength and stiffness by the laminating process does not justify the use of low quality logs but rather logs of middle or high quality since LVL components are used as structural members requiring high design values. $L V L$ members are used as truss components, I-beam flanges, scaffold planks and floor joists. LVL members can be also produced in $2.44 \mathrm{~m}$ ( 8 foot [']) lengths without veneer joints in commercial softwood plywood presses, cut them into lumber and then finger- or scarf-joint the ends into longer lengths. Such members retain most of the previously listed advantages if they are used in composite structures where the joints are allowed to distribute stresses to adjacent materials, as in the case of flanges of wood I-beams and laminated built-up beams.

A study by Stump et al (1981) concerned with properties of LVL produced from eastern plantation grown conifers. A recent study (Kretchamann et al, 1993) investigated properties of Douglas fir and southern yellow pine LVL from mature and juvenile wood veneers of the same nondestructively determined grade. This study found a significant difference in flexural strength and stiffness between LVL from mature and juvenile veneers. 


\section{PROCEDURE}

\section{Materials and fabrication}

Logs $2.59 \mathrm{~m}\left(8.5^{\prime}\right)$ long from the following loblolly pine (Pinus taeda $L$ ) forest stands in Alabama were used in this study: i) a 20-year-old plantation with original spacing $2.44 \times 2.44 \mathrm{~m}\left(8 \times 8^{\prime}\right)$ and thinned at age 15; ii) a 28 -year-old natural stand; and iii) a 40-year-old well-stocked natural stand.

Several logs from each of these stands were peeled into $0.32 \mathrm{~cm}(1 / 8$ ") thick veneers and cut into $1.32 \mathrm{~m}$ (52") wide $\times 2.59 \mathrm{~m}$ (102") long veneer sheets in a southern yellow pine plywood mill. In addition, some logs from the 20-year-old plantation were peeled into $0.23 \mathrm{~cm}(1 / 10$ ") thick veneers. All veneers from each group and thickness were dried in the mill to approximately $7 \%$ moisture content (oven-dry basis). Dry veneers were graded according to American Plywood Association standards (1983).

Four LVL panels, $3.8 \mathrm{~cm}(1.5$ ") thick and $1.22 \mathrm{~m}$ (4') wide by $2.44 \mathrm{~m} \mathrm{(8')} \mathrm{long} \mathrm{were} \mathrm{fabricated} \mathrm{wi-}$ thout veneer joints from each of the first five LVL groups described in table I, while only one LVL panel was fabricated from each of the 'composite' LVL groups in the same table. Fabrication of each panel was a two-step process in order to shorten the total pressing time of the panels. The first step was to fabricate a $1.9 \mathrm{~cm}(3 / 4$ ") thick panel to be used as a core for each final $3.81 \mathrm{~cm}$ (1.5") thick panel. A commercial extended phenolic resin (the same used by the sawmill in the fabrication of plywood) was applied to veneers with a curtain coater at a rate of $41.7 \mathrm{~kg}(92$ pounds) per $92.9 \mathrm{~m}^{2}$ (1 000 square feet) of double glue line. Those core panels consisted of seven $0.32 \mathrm{~cm}\left(1 / 8^{\prime \prime}\right)$ veneers or eight $0.25 \mathrm{~cm}$ $\left(1 / 10^{\prime \prime}\right)$ veneers and were first prepressed in room temperature with $1103 \mathrm{Kpa}$ (160 psi) for 3 min. Afterwards, the panels were hot pressed in a multiple press (one panel in each opening) for 7.5 min at $163^{\circ} \mathrm{C}$ with $1379 \mathrm{Kpa}$ (200 psi).

The second step for fabricating the panels of the first five groups in table I consisted of laying three $0.32 \mathrm{~cm}\left(1 / 8^{\prime \prime}\right) \mathrm{B}$ - or C-grade veneers of $0.95 \mathrm{~cm}(0.375$ ") total thickness or four $0.25 \mathrm{~cm}$ $\left(1 / 10^{\prime \prime}\right)$ veneers then placing on top of them the already fabricated $1.9 \mathrm{~cm}(3 / 4 ")$ thick core panel and finally laying on top three $0.32 \mathrm{~cm}(1 / 8$ ") or four $0.25 \mathrm{~cm}(1 / 10 ")$ additional veneers, respectively, for a total of 13 or 16 veneer layers in each panel $4.19 \mathrm{~cm}\left(1.65^{\prime \prime}\right)$ thick.
The second step for fabricating the 'composite 1 ' panel consisted of laying one B-grade veneer from a 40-year-old tree, one B-grade and one $\mathrm{C}$-grade veneer from a 20-year-old tree, then placing on top the already fabricated $1.9 \mathrm{~cm}$ $(3 / 4 ")$ thick panel and finally laying on top three additional veneers of the same grades and age on the three veneers at the bottom.

The second step for fabricating the 'composite 2 ' panel was similar to fabricating 'composite 1' except that two veneers at the bottom and top were B-grade veneers from a 40-year-old tree and one $\mathrm{C}$-grade veneer from a 20 -year-old tree. All assemblies at the second step were pre-pressed and then hot-pressed with the same schedule of temperature, time and pressure as the 1.9 $\mathrm{cm}(3 / 4 ")$ thick panel in the first step.

All fabricated panels were stacked-up for $48 \mathrm{~h}$ to cool-off before sawing them into lumber. A strip $5.08 \mathrm{~cm}$ (2") wide was removed from the long edge of each panel while the remaining panel was sawed into 12 LVL strips $9.14 \mathrm{~cm}$ (3.6") wide. Each LVL strip was dressed at the planer to cross-section dimensions $3.81 \times 8.89 \mathrm{~cm}$ $(1.5 \times 3.5 ")$ and $2.59 \mathrm{~m}$ (102") long. Forty-eight pieces of LVL from each of the first five groups and 12 pieces from each 'composite' panel were available for a full-size flexure test.

Several logs $2.59 \mathrm{~m}\left(8^{\prime} 5^{\prime}\right)$ long from each of the three forest stands were separated and endpainted with different colors to identify each stand. All logs were sawn into lumber according to the sawing pattern of the cooperating sawmill. All lumber was kiln-dried to $15 \% \mathrm{MC}$. All lumber of various sizes was dressed to final dimensions and then graded by the mill's graders according to Southern Pine Inspection Bureau (SPIB) grading rules (1991). Approximately 30 pieces of $3.81 \times 8.9 \mathrm{~cm}\left(1.5 \times 3.5^{\prime \prime}\right)$ lumber from each of the three grades $(1,2$ and 3$)$ and from each stand were separated for flexure testing.

\section{TESTING}

The following properties of LVL and solid sawn lumber were evaluated.

\section{Edgewise flexural strength (modulus of rupture, MOR) and edgewise flexural stiffness, MOE)}

From each LVL panel group listed in table I, 12 to 33 pieces $3.81 \times 8.89 \mathrm{~cm}(1.5 \times 3.5$ ") were tested. In addition, 28 pieces of the same dimensions, 


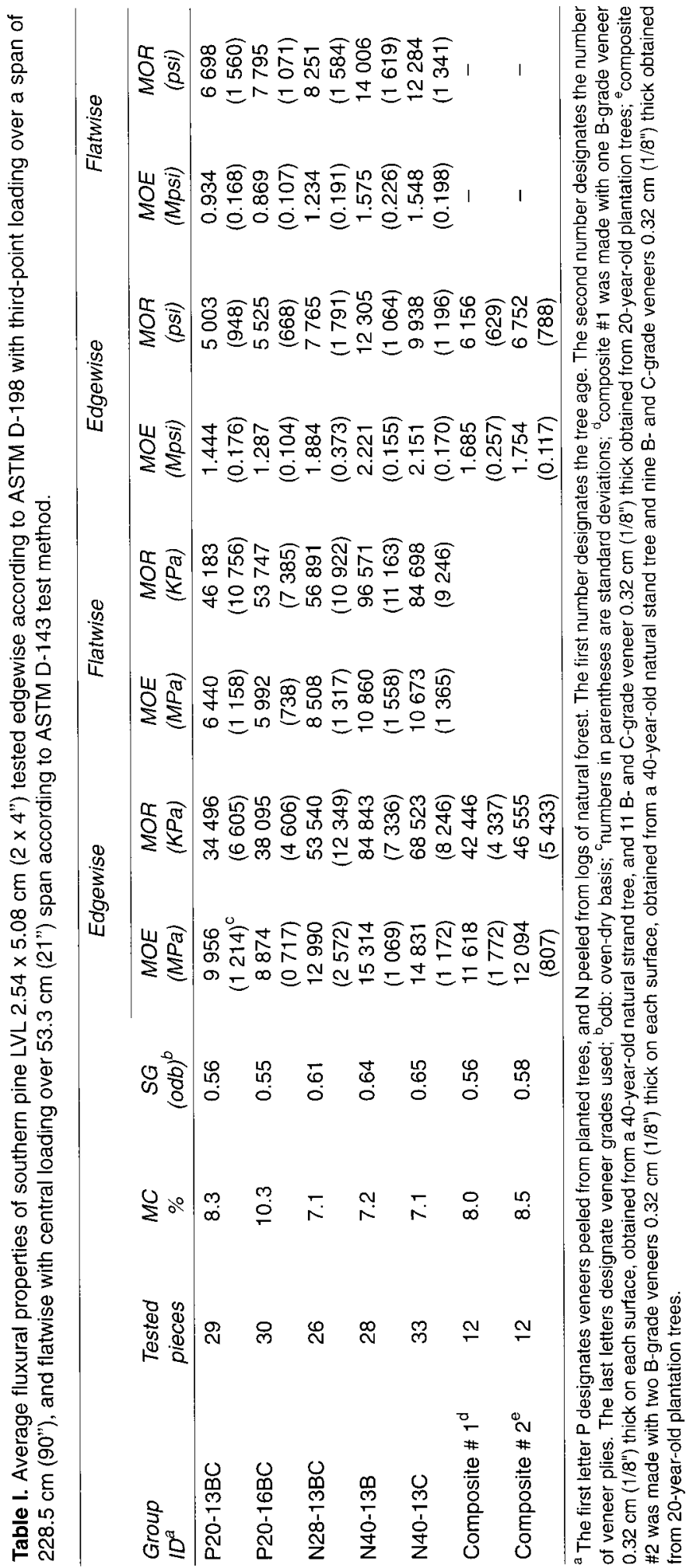


from each of the three lumber grades, from each of the 20- and 28-year-old stands were also tested. All edgewise flexural tests were made to failure according to ASTM D-198 (1991) with thirdpoint loading over a span of $2.29 \mathrm{~m}$ (90") as indicated in figure 1. After testing, the moisture content percentage (MC) and specific gravity (SG) of each tested piece were determined from a cross-sectional sample taken in the vicinity of the failure.

\section{Flatwise flexural strength (MOR) and flatwise flexural stiffness (MOE)}

From each LVL tested piece in edgewise flexure, except for composites, an undamaged section, $58.4 \mathrm{~cm}$ long, was taken and tested in flexure flatwise to failure according to ASTM D-143 (1991) with central loading over a span of $53.3 \mathrm{~cm}$ (21").

\section{Wood block shear strength}

From each LVL group listed in table I, except for composites, approximately 60 wood block shear specimens were prepared to test the shear strength perpendicular to the glue line. The test was done according to the ASTM D-143 test method (1991).

In addition, approximately 48 wood block shear strength specimens were prepared from lumber representing the 20 -year-old stand and 48 specimens representing the 28 -year-old stand. The test was done according to the ASTM D-143 test method (1991).

\section{RESULTS AND DISCUSSION}

The flexural properties of the LVL tested groups are listed in table I while the flexural properties of the solid sawn lumber from the three forest stands are listed in table II. The results indicate the following: The flexural properties MOR and MOE of LVL from the 20-year-old plantation are significantly (differences of the means tested with $t$-test and found significant at the $99 \%$ level) lower than corresponding properties of LVL

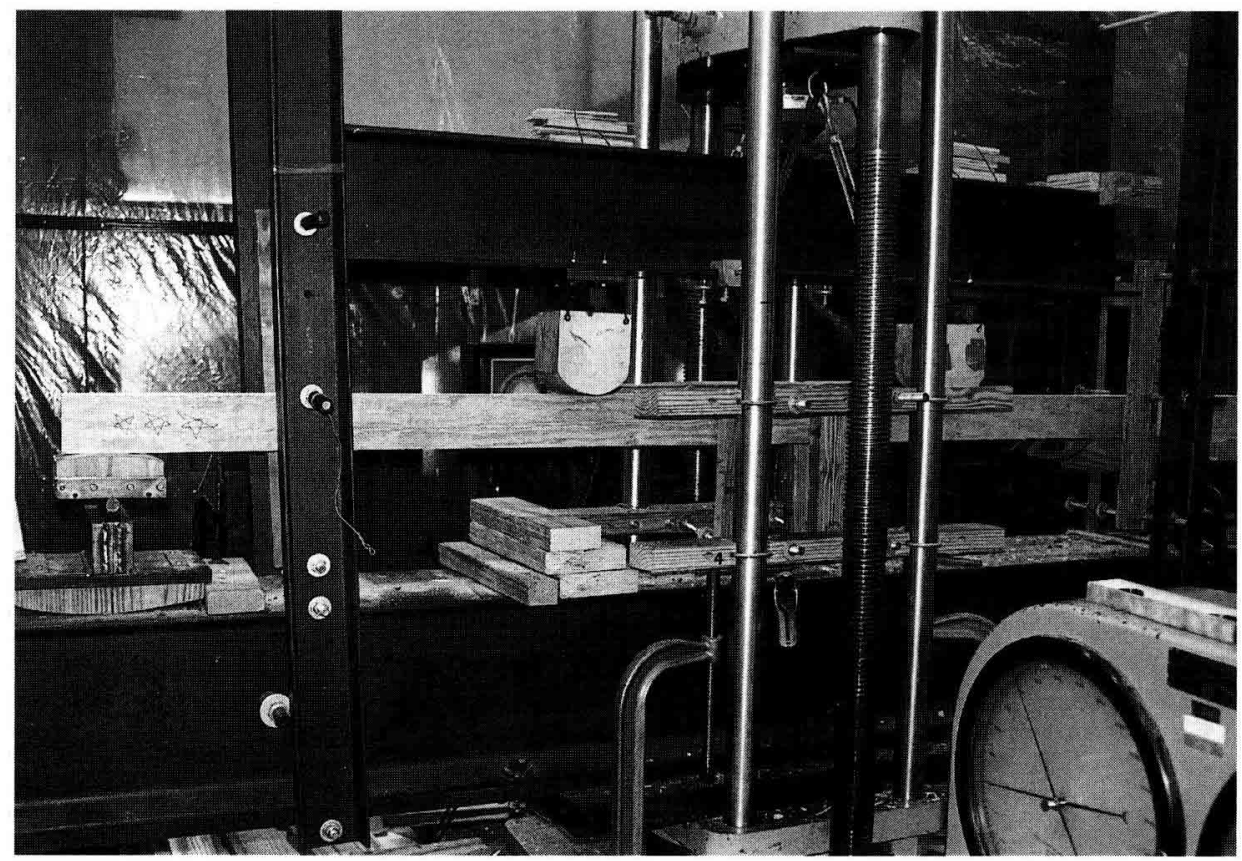

Fig 1. Edgewise flexural test of an LVL member $3.81 \times 8.89 \mathrm{~cm}(1.5 \times 3.5$ ") cross section tested to failure with third-point loading over a span of $2.29 \mathrm{~m}(90$ ") according to ASTM D-198 test method. 
Table II. Average flexural properties of $5.1 \times 10.2 \mathrm{~cm}(2 \times 4$ ") southern pine lumber grades 1,2 and 3 tested edgewise according to the ASTM D-198 method with third-point loading over a span of $228.6 \mathrm{~cm}(90 ")$.

\begin{tabular}{|c|c|c|c|c|c|c|c|}
\hline \multirow[b]{2}{*}{$\begin{array}{l}\text { Group } \\
I D^{a}\end{array}$} & \multirow[b]{2}{*}{$\begin{array}{l}\text { Tested } \\
\text { pieces }\end{array}$} & \multirow[b]{2}{*}{$\begin{array}{c}M C \\
\%\end{array}$} & \multirow[b]{2}{*}{$\begin{array}{c}S G \\
(o d b)^{b}\end{array}$} & \multicolumn{4}{|c|}{ Edgewise } \\
\hline & & & & $\begin{array}{l}M O E \\
(M P a)\end{array}$ & $\begin{array}{l}\text { MOR } \\
(K P a)\end{array}$ & $\begin{array}{c}M O E \\
\text { (Mpsi) }\end{array}$ & $\begin{array}{c}\text { MOR } \\
(p s i)\end{array}$ \\
\hline P20-No.1 & 10 & 9.8 & 0.47 & $\begin{array}{c}7860 \\
(2344)^{c}\end{array}$ & $\begin{array}{c}37805 \\
(11680)\end{array}$ & $\begin{array}{c}1.314 \\
(0.340)\end{array}$ & $\begin{array}{c}5483 \\
(1684)\end{array}$ \\
\hline P20-No.2 & 28 & 9.9 & 0.47 & $\begin{array}{c}8446 \\
(2565)\end{array}$ & $\begin{array}{c}28235 \\
(14424)\end{array}$ & $\begin{array}{c}1.225 \\
(0.372)\end{array}$ & $\begin{array}{l}4095 \\
(2092)\end{array}$ \\
\hline P20-No.3 & 29 & 10.2 & 0.45 & $\begin{array}{c}5785 \\
(2262)\end{array}$ & $\begin{array}{c}21064 \\
(10356)\end{array}$ & $\begin{array}{c}0.839 \\
(0.328)\end{array}$ & $\begin{array}{c}3055 \\
(1502)\end{array}$ \\
\hline N28-No.1 & 29 & 10.8 & 0.54 & $\begin{array}{l}13714 \\
(2613)\end{array}$ & $\begin{array}{c}57884 \\
(19403)\end{array}$ & $\begin{array}{c}1.989 \\
(0.379)\end{array}$ & $\begin{array}{c}8395 \\
(2814)\end{array}$ \\
\hline N28-No.2 & 28 & 9.6 & 0.51 & $\begin{array}{l}12301 \\
(2641)\end{array}$ & $\begin{array}{c}44714 \\
(17272)\end{array}$ & $\begin{array}{c}1.784 \\
(0.383)\end{array}$ & $\begin{array}{c}6485 \\
(2505)\end{array}$ \\
\hline N28-No.3 & 28 & 9.3 & 0.50 & $\begin{array}{c}9860 \\
(2310)\end{array}$ & $\begin{array}{c}31062 \\
(15052)\end{array}$ & $\begin{array}{c}1.430 \\
(0.335)\end{array}$ & $\begin{array}{c}4505 \\
(2183)\end{array}$ \\
\hline
\end{tabular}

${ }^{2}$ The first letter $P$ designates lumber sawn from planted trees, $\mathrm{N}$ lumber from logs of natural stands. The first number designates the tree age. The second number designates SPIB lumber grade; 'odb: oven-dry basis; "numbers in parentheses are standard deviations.

fabricated from veneers of oider natural stands. The average edgewise MOR of the 20-year-old LVL's P20-13 BC and P20-16 BC (36296 KPa or 5264 psi) is only 68 and $53 \%$ of the edgewise MOR values of LVL from the 28- and 40-year-old natural stands, respectively. Similarly, the average MOE of LVLs of the 20 -year-old plantation is only $73 \%$ and $63 \%$ of edgewise MOE values of LVL from the 28- and 40-year-old natural stands, respectively. The same tendency exists in the flatwise flexural properties.

Table I also indicates that the average MOR value of the 20-year-old plantation LVL with thinner veneer plies $0.25 \mathrm{~cm}\left(1 / 10^{\prime \prime}\right)$ is slightly greater than that of LVL with $0.32 \mathrm{~cm}(1 / 8$ ") thick veneers. However, the reverse is true concerning the edgewise MOE values. Therefore, the results do not indicate a favorable effect of veneer thick-ness on flexural properties of LVL based on veneer thicknesses considered in this study.

The edgewise flexural MOE of every LVL group in this study (table I) is between 39 and $55 \%$ larger than the flatwise flexural
MOE of each group. This can be explained by the fact that the edgewise stiffness was determined with third-point loading, a method which eliminates shear deflection between the loading points and thus gives higher MOE values. On the other hand, the flatwise strength (MOR) of every LVL group is, on average, $25 \%$ greater than the edgewise MOR value in each group.

There is a significant (differences of the means tested with $t$-test and found significant at the $99 \%$ level) effect of B- and Cgrade veneers, especially on the MOR values and on the MOE of LVL from the 40year-old natural stand. The LVL produced from the B-grade veneers is, on average, $18 \%$ stronger than LVL produced from the $\mathrm{C}$-grade veneers.

The average edgewise flexural properties, MOR and MOE, of the composites are significantly higher than the corresponding properties of LVL representing the 20-yearold trees. Composite 1 with a $15 \%$ of the total volume in B-grade veneer from $40-$ year-old trees, provides an increase of $23 \%$ 
in MOR and $17 \%$ in MOE. Composite 2 with a $31 \%$ of the total volume in B-grade veneer from 40-year-old trees, provides an increase of $35 \%$ in MOR and $22 \%$ in MOE.

The average edgewise flexural properties of LVL from the 20-year-old plantation shown in table $\mathrm{I}$ are between the corresponding values of sawn lumber grades No 1 and No 2 from logs of the same stand shown in table II. On the basis of the average MOE value alone (8 $874 \mathrm{MPa}$ or 1287928 psi of LVL P2O$16 \mathrm{BC}$ ), these specimens do not qualify to be graded even as a 'standard' SPIB grade (the lowest of all grades). If we consider the combined MOE value 9417 MPa (1 365829 psi) of both LVL groups, P20-13BC and P20$16 \mathrm{BC}$, then combine them as one group, on the basis of stiffness value alone, they qualify only as a 'standard' SPIB grade. Table III shows that $95 \%$ of the LVL pieces made from 20 -year-old trees with $0.32 \mathrm{~cm}(1 / 8$ ") thick veneers (P20-13BC) have design values for bending ' $\mathrm{Fb}$ ' (calculated for every tested piece by dividing the MOR value of every piece by the 2.1 adjustment factor recommended in ASTM D245-88 [1991]) and ' $E$ ' that belong to SPIB lumber 2 none dense and lower. Table III also shows that $93 \%$ of the LVL pieces made with $0.42 \mathrm{~cm}\left(1 / 6^{\prime \prime}\right)$ thick ve- neers (P20-16BC) have design values that belong to the lowest SPIB lumber 'standard' grade. Thus, it appears that fabrication of LVL from the 20-year-old plantation does not provide any improvement over the properties and design values of the sawn solid lumber of this material.

The average edgewise flexural properties of LVL from the 28-year-old natural (N2813BC) stand shown in table I (MOE $=12994$ $\mathrm{MPa}$ or $1884588 \mathrm{psi}$; MOR = $53540 \mathrm{KPa}$ or $7765 \mathrm{psi}$ ) are larger than the corresponding properties for grade 2 lumber of the same stand shown in table II. Table III indicates $56 \%$ of the LVL pieces of the same stand have design values for bending equal to SPIB grade 'dense select structural' ( $\mathrm{Fb}=21029$ Kpa or 3050 psi; MOE = $13100 \mathrm{MPa}$ or 1.9 Mpsi), $20 \%$ of the pieces with design value equal to lumber grade 2 and better and $24 \%$ of the pieces with design value equal to lumber of 'standard' grade. Table III also shows that $100 \%$ of the LVL pieces tested from the 40-year-old natural stand have design values for bending equal to SPIB grade 'dense select structural'. It appears therefore that the laminating process to produce LVL from trees of older than 28-year-old natural stands improves the properties and design

Table III. Number of pieces and corresponding percentages of assigned SPIB lumber grades based on the edgewise properties of tested southern pine LVL $5.1 \times 10.2 \mathrm{~cm}$ ( $2 \times 4$ ").

\begin{tabular}{|c|c|c|c|c|c|c|c|c|c|c|c|}
\hline \multirow{2}{*}{$\begin{array}{l}\text { Group } \\
1 D^{\mathrm{a}}\end{array}$} & \multirow{2}{*}{$\begin{array}{l}\text { Tested } \\
\text { pieces }\end{array}$} & \multicolumn{3}{|c|}{ Edgewise } & \multirow{2}{*}{$\begin{array}{l}D S S \\
1.9 M \\
3050\end{array}$} & \multirow{2}{*}{$\begin{array}{l}\text { NDSS } \\
1.7 \mathrm{M} \\
2650\end{array}$} & \multirow{2}{*}{$\begin{array}{c}S S \\
1.8 M \\
2850\end{array}$} & \multirow{2}{*}{$\begin{array}{c}1 \\
1.7 M \\
1850\end{array}$} & \multirow{2}{*}{$\begin{array}{l}\text { IND } \\
1.6 \mathrm{M} \\
1700 \\
\end{array}$} & \multirow{2}{*}{$\begin{array}{c}2 N D \\
1.4 M \\
1350 \\
\end{array}$} & \multirow{2}{*}{$\begin{array}{c}\text { STD } \\
1.3 M \\
625 \\
\end{array}$} \\
\hline & & $\begin{array}{c}M O E \\
(M p s i)\end{array}$ & $\begin{array}{c}\text { MOR } \\
\text { (psi) }\end{array}$ & $\begin{array}{l}E: \\
F b:\end{array}$ & & & & & & & \\
\hline P20-13BC & 29 & $\begin{array}{l}1.443 \\
(0.176)\end{array}$ & $\begin{array}{l}5003 \\
(948)\end{array}$ & & & & & & $\begin{array}{l}2 \\
7 \%\end{array}$ & $\begin{array}{l}16 \\
57 \%\end{array}$ & $\begin{array}{l}11 \\
38 \%\end{array}$ \\
\hline $\mathrm{P} 20-16 \mathrm{BC}$ & 30 & $\begin{array}{l}1.287 \\
(0.104)\end{array}$ & $\begin{array}{l}5525 \\
(668)\end{array}$ & & & & & & & $\begin{array}{l}2 \\
7 \%\end{array}$ & $\begin{array}{l}28 \\
93 \%\end{array}$ \\
\hline N28-13BC & 25 & $\begin{array}{l}1.884 \\
(0.373)\end{array}$ & $\begin{array}{l}7765 \\
(1791)\end{array}$ & & $\begin{array}{l}14 \\
56 \%\end{array}$ & & & & $\begin{array}{l}1 \\
4 \%\end{array}$ & $\begin{array}{l}4 \\
16 \%\end{array}$ & $\begin{array}{l}6 \\
24 \%\end{array}$ \\
\hline N40-13B & 24 & $\begin{array}{l}2.221 \\
(0.155)\end{array}$ & $\begin{array}{l}12305 \\
\left(\begin{array}{l}1064)\end{array}\right)\end{array}$ & & $\begin{array}{l}24 \\
100 \%\end{array}$ & & & & & & \\
\hline$N 40-13 C$ & 33 & 2.151 & 9938 & & 32 & & & & & & \\
\hline
\end{tabular}

\footnotetext{
${ }^{a}$ See footnotes in table I; 1 psi $=6.895 \mathrm{KPa}$.
} 
values of sawn lumber from trees of these stands.

Table III also shows that $67 \%$ of the tested LVL specimens of composite 1 have design values that belong to lumber grade 1 and better. This table indicates that $67 \%$ of the tested LVL specimens of composite 2 have design values that belong to lumber 'select structural' grade and better.

This finding indicates that a significant structural improvement can be made by reinforcing LVL made from 20-year-old plantation trees with four $B$-grade veneers $(31 \%$ of LVL volume) of 40-year-old mature trees.

The shear strength of LVL specimens perpendicular to the glue line of LVL from the 20-year-old plantation was $7695 \mathrm{KPa}$ or $1116 \mathrm{psi}$ and $8667 \mathrm{KPa}$ or $1257 \mathrm{psi}$ for the $0.32 \mathrm{~cm} \mathrm{(1/8")} \mathrm{and} 0.25 \mathrm{~cm}(1 / 10 ")$ thick veneer, respectively, as shown in table IV. These values are approximately equal to shear strength of solid sawn wood 8171 $\mathrm{KPa}$ (1 $185 \mathrm{psi}$ ) from logs of the same stand. The shear strength of LVL perpendi- cular to grain from the 28-year-old natural stand was $9350 \mathrm{KPa}$ (1 $356 \mathrm{psi}$ ). This value, however, is only $78 \%$ of the shear strength value of solid sawn wood 11950 $\mathrm{KPa}$ (1 $733 \mathrm{psi}$ ) from logs of the same stand. The lower shear strength value of the LVL can be explained by the possible effect of the veneer lathe checks in the LVL. This, however, needs to be verified with additional well controlled experiments.

\section{CONCLUSION}

The results of this study indicate that: i) The edgewise flexural properties MOR and MOE of LVL fabricated from the 20-year-old plantation are significantly lower than corresponding properties of LVL fabricated from veneers of older natural stands. The average MOR and MOE values of LVL from the 20 -year-old trees are only 54 and $63 \%$, respectively, of the properties of LVL from 40 -year-old trees from natural stands. ii) There is a significant effect of the veneer

Table IV. Average wood block shear strength of southern pine LVL and solid wood specimens cut from $5.08 \times 10.2 \mathrm{~cm}(2 \times 4$ ") lumber, and tested according to the ASTM D-143 method.

\begin{tabular}{|c|c|c|c|c|c|}
\hline \multirow{2}{*}{$\begin{array}{l}\text { Group } \\
1 D^{a}\end{array}$} & \multirow{2}{*}{$\begin{array}{l}\text { Tested } \\
\text { pieces }\end{array}$} & \multirow{2}{*}{$\begin{array}{l}M C \\
(\%)\end{array}$} & \multirow{2}{*}{$\begin{array}{c}S G \\
(o d b)^{b}\end{array}$} & \multicolumn{2}{|c|}{ Shear strength } \\
\hline & & & & $K P a$ & psi \\
\hline \multicolumn{6}{|l|}{ LVL } \\
\hline $\mathrm{P} 20-13 \mathrm{BC}$ & 60 & 8.4 & 0.55 & $\begin{array}{r}7695 \\
(1117)^{c}\end{array}$ & $\begin{array}{l}1116 \\
(162)\end{array}$ \\
\hline P20-16BC & 60 & 10.3 & 0.56 & $\begin{array}{c}8667 \\
(1345)\end{array}$ & $\begin{array}{l}1257 \\
\text { (195) }\end{array}$ \\
\hline N28-13BC & 58 & 7.1 & 0.60 & $\begin{array}{l}9350 \\
(958)\end{array}$ & $\begin{array}{l}1356 \\
\text { (139) }\end{array}$ \\
\hline $\mathrm{N} 40-13 \mathrm{~B}$ & 60 & 7.1 & 0.65 & $\begin{array}{l}10894 \\
(1186)\end{array}$ & $\begin{array}{l}1580 \\
(172)\end{array}$ \\
\hline $\mathrm{N} 40-13 \mathrm{C}$ & 60 & 8.9 & 0.62 & $\begin{array}{c}9453 \\
(1158)\end{array}$ & $\begin{array}{l}1371 \\
(168)\end{array}$ \\
\hline \multicolumn{6}{|l|}{ Solid wood } \\
\hline P20 & 48 & 10.2 & 0.51 & $\begin{array}{c}8171 \\
(1462)\end{array}$ & $\begin{array}{l}1185 \\
(212)\end{array}$ \\
\hline N28 & 45 & 12.5 & 0.55 & $\begin{array}{r}11949 \\
(1345)\end{array}$ & $\begin{array}{l}1733 \\
(195)\end{array}$ \\
\hline
\end{tabular}

${ }^{a}$ See footnote in table I; ${ }^{b}$ od: stands for oven-dry basis; "numbers in parenthesis are standard deviations. 
grades ( $B$ and $C$ grades) particularly on the flexural strength of LVL from 40-year-old trees, where LVL made with B-grade veneers is, on average, is $18 \%$ stronger than LVL made from $C$ - grade veneers. iii) Fabrication of LVL from 20-year-old plantation trees does not provide improvement over the properties and design values of $\mathrm{N}^{\circ} 1$ and 2 sawn solid lumber of this material. iv) Inclusion of veneer from mature trees significantly improved the strength and stiffness of LVL made exclusively from 20-year-old plantation trees. Inclusion of $31 \%$ of $\mathrm{B}$ grade veneers from a mature tree to $69 \%$ $\mathrm{B}$ - and C-grade veneers from 20-year-old plantation trees significantly improved the flexural strength of the composite LVL by $35 \%$, compared to LVL made exclusively from veneers of 20-year-old plantation trees. v) The shear strength of LVL perpendicular to the glue line from the 20-year-old trees are not significantly different from the shear strength value of solid wood specimens from the same trees. vi) The shear strength of LVL perpendicular to glue line from the 40-year-old trees from the natural stand are significantly higher than the shear strength of LVL from the 20-year-old plantation trees.

\section{REFERENCES}

American Plywood Association (1983) US Product Standard for construction and industrial plywood. $P$ 51-83. Tacoma, WA, USA

American Society for Testing and Materials (ASTM) (1991) Standard methods of static tests of timbers in standard sizes, D 198-84. Standard method of testing small clear specimens of timber D 143-83. In: American Book of ASTM Standards, Section 4 vol 04.09, Philadelphia, PA, USA

Bendtsen BA, Senft J (1986) Mechanical and anatomical properties in individual growth rings of plantation- grown eastern cottonwood and loblolly pine. Wood Fiber Sci 18, 23-38

Bendtsen BA (1978) Properties of wood from improved and intensively managed trees. Forest Prod $J 28$, $61-72$

Biblis EJ, Brinker R, Carino H, McKee CW (1993) Effect of stand age on flexural properties and grade compliance of lumber from loblolly pine plantation timber. Forest Prod J 43, 23-28

Bohlen JC (1975) Shear strength of Douglas-fir laminated-veneer lumber. Forest Prod J 25, 16-23

FPL Press-Lam Research Team (1977) Progress in Technical Development of Laminated Veneer Structural Products. USDA Forest Service Res Pap FPL 279. Forest Prod Lab, Madison, WI, USA

Koch P (1973) Structural lumber laminated from $1 / 4$ inch rotary-peeled southern pine veneer. Forest Prod $J$ $23,17-25$

Kretchamann DE, Moody RC, Pellevin RF, Bendtsen BA, Cahill JM, McAllister RH, Sharp DW (1993) The effect of various proportions of juvenile wood on LVL. USDA FPL RP-521. Forest Products Lab, Madison, WI, USA

Kunesh RH (1978) MICRO = LAM: structural laminated veneer lumber. Forest Prod $J 28,41-44$

MacPeak MD, Burkart LF, Weldon D (1990) Comparison of grade, yield, and mechanical properties of lumber produced from young fast-grown and older slowgrown planted slash pine. Forest Prod J 40, 11-14

Pearson RG, Gilmore RC (1980) Effect of fast growth rate on the mechanical properties of loblolly pine. Forest Prod J 30, 47-54

Pearson RG, Gilmore RC (1971) Characterization of the strength of juvenile wood of loblolly pine (Pinus taeda L). Forest Prod J 21, 23-30

Laufenberg TL (1983) Parallel-laminated veneer processing and performance research review. Forest Prod J 33, 21-28

Moody RC, Peters CC (1972) Strength properties of rotary knife-cut laminated southern pine. USDA Forest Serv, Res Pap FPL 178, Forest Products Lab, Madison, WI, USA

Nelson SA (1972) Structural applications of MICRO$=$ LAM lumber. Civ Eng 42, 57

Southern Pine Inspection Bureau (1991) Grading Rules. SPIB, Pensacola, FL, USA

Stump JP, Smith LA, Gray RL (1981) Laminated Veneer Lumber made from plantation-grown conifers. For Prod J 31, 35-40 